Sitasi artikel ini (APA $6^{\text {th }}$ Edition style):

Sahfutra, S. A. (2018). Konstruksi Konflik dan Bina-Damai dalam Keberagaman Masyarakat Jawa. MUKADIMAH, 2(1), 28-43.

\title{
Konstruksi Konflik dan Bina-Damai dalam Keberagaman Masyarakat Jawa
}

\author{
Suryo Adi Sahfutra \\ Fakultas Ilmu Sosial, UIN Sumatera Utara \\ suryaadisahfutra@gmail.com
}

\begin{abstract}
ABSTRAK
Agama dalam perspektif sosiologis sering muncul dalam dua wajah ganda, yaitu sebagai sumber konflik sekaligus sumber bina-damai. Faktanya, sulit dihindari bahwa adanya pemahaman yang menguatkan eskalasi konflik bersumber dari pemahaman ajaran agama, begitu juga sebaliknya proses bina-damai. Dalam konstruksi masyarakat Jawa, konflik dan bina-damai juga memiliki kekuatan dan kelemahannya masing-masing. Setidaknya dalam riset ini ditemukan bahwa masyarakat Jawa lebih memilih hidup rukun daripada konflik. Watak yang demikian mendominasi alam berpikir masyarakat Jawa. Oleh karena itu, bangunan tentang kedamaian mewujud tidak hanya dengan manusia melainkan juga dengan alam. Banyaknya prosesi ritualistik yang dibangun dalam sistem budaya menunjukkan bahwa orang Jawa senantiasa ingin berdamai dengan semua makhluk yang ada di alam raya.
\end{abstract}

Kata kunci: Konflik, bina-damai, masyarakat Jawa, integrasi.

\section{PENDAHULUAN}

Secara spesifik telaah atas kebudayaan Jawa yang melingkupi berbagai dimensi filosofis, kajian tentang bagaimana orang Jawa menjalani hidup tentu sudah banyak dilakukan oleh para ahli sosiologi dan antropologi, ini mengindikasikan bahwa prilaku manusia Jawa secara umum selalu multidemensi. Kultur Jawa atau tradisi Jawa terkait dengan relasi personal, orang ke orang, antar kelompok dan komunitas tidak serta merta dibangun atas dasar alamiah begitu saja, ada landasan berpikir dan bertindak yang menjadi pondasi sumber nilai dalam setiap gerak kehidupannya, tentu ini bukan hanya berlaku bagi etnis Jawa begitu juga dengan etnis lainnya.

Persoalan relasi antar individu, kelompok atau komuntas dalam sistem kultur Jawa menjadi pondasi atas bentuk dan konstruksi hubungan tersebut, kerukunan menjadi pilar penyangga kehidupan harmonis baik sesama manusia maupun dengan alam. Konsepsi kerukunan dalam sistem kebuyaan Jawa erat kaitanya dengan integrasi masyarakat secara spesifik msyarakat desa yang masih memegang teguh norma dan etika budaya. 
Integrasi sebuah msyarakat dengan adanya kerukunan tidak berarti menghilangkan konflik, apalagi dalam masyarakat majemuk baik agama maupun etnis. Konflik disini dapat berbentuk laten dan manifest. Dahrendorf menyebutkan bahwa permasalahan serius yang kerap muncul dalam kehidupan bermasyarakat adalah konflik kepentingan. Bentuk interest conflict kerap muncul dalam kehidupan masyarakat, masyarakat yang homogen maupun heterogen terjebak dalam nuansa konflik ketika kepentingan yang dimiliki masing-masing individu maupun kelompok saling bertentangan (incompability) dan sulit dicari penyelesaiannya (Ritzer, 1982). Pihak yang satu menginginkan kepentingannya diutamakan, sedangkan pihak yang lain juga memiliki keinginan yang serupa. Pergeseran dua kepentingan yang dimiliki dua kelompok berbeda, tidak jarang juga memancing timbulnya konflik.

Dalam mewadahi kepentingan yang berbeda masyarakat desa yang pada umumnya agraris, yaitu masa interaksi sosial masih menggantungkan pada pola-pola kinship (Gemeinschaft pattern), konflik yang terjadi biasanya terkait dengan pola persaingan dalam upaya pemenuhan kebutuhan fisik dan perolehan kekayaan pribadi (From, 2001, p. 229; Parsons, 1997, p. 153; Thomshon, 1996, pp. 23-26). Penyelesaian konflik yang terjadi dalam interaksi kekeluargaan, tergantung pada kewibawaan seseorang yang paling dihormati dalam kelompok yang diharapkan mampu menyelesaikan permasalahan. Metode mediasi ini terbukti efektif, sebab hubungan yang ada masih menggunakan standar kekeluargaan (Koentjaraningrat, 1981, p. 158).

Menghadapi berbagai potensi konflik yang oleh Menurut Hobbes dijelaskan bahwa konflik merupakan gejala instrintik yang tidak mungkin dihindarkan dalam kehidupan manusia, semua literatur peradaban manusia mencatat konflik sosial pada masanya (Windhu, 1991, p. 63). Berbeda dengan Hobbes, Roger M. Keesing menyatakan bahwa manusia memiliki sifat alamiah untuk terlibat dalam konflik. Hal ini dapat kita ketahui dari perilaku agresif yang dimiliki manusia, ingin merampas wilayah, dan bersaing dengan sesamanya. Manusia laki-laki cenderung memiliki sifat dominan kepada pihak wanita, sebaliknya pihak wanita juga memiliki kecenderungan menguasai lakilaki (Keesing, 1999, p. 20).

Menyadari bahwa konflik adalah bagian dari elemen kehidupan, kultur Jawa membangun pemahaman tentang arti pentingnya sebuah kerukunan dalam sebuah masyarakat yang akan membentuk satu integrasi sosial. Faktor pendukung yang menjadikan masyarakat Jawa pada umumnya memiliki integrasi sosial yang baik adalah adanya konsep 'guyup rukun' dalam kehidupan rumah tangga dan bertetangga yang bersumber dari kebudayaan Jawa (Neils Mulder, 1984, p. 64). Pada sisi lain, bentuk kehidupan keberagamaan (religiositas) yang tertutup atau fanatik merupakan sumber konflik sosial dalam kehidupan masyarakat (Kleden, 1984).

Hal lain yang menjelaskan tentang masyarakat Jawa dalam beragama adalah uraian dari Frans Magnis Suseno yang mengatakan dengan jelas bahwa orang Jawa membenci dogmatisme, eksklusivisme, fanatisme, kepicikan agama dan kesombongan. Bukan seakan-akan agama adalah urusan pribadi semata, 
melainkan orang harus merasakan ke mana dan di mana, Tuhan memanggilnya. Dalam budaya Jawa, otonomi orang untuk menemukan sendiri di dasar jiwanya tentang Tuhan sangat dihormati (Magnis-Suseno, 2007, p. 61).

Ada tiga hal yang menjadi sumber konflik dalam masyarakat Indonesia, setidaknya analisis dari Koentjaraningrat mengemukakan hal tersebut, antara lain ketika antar warga masyarakat: saling bersaing dalam lapangan mata pencaharian, saling memaksakan unsur-unsur dari kebudayaannya dan atau agamanya dan terakhir saling mendominasi secara politik (Koentjaraningrat, 1979, p. 377).

\section{KERANGKA TEORETIK DAN KONSEPTUAL}

Semua agama pada dasarnya menolak kekerasan sebagai prinsip dalam setiap aktivitas tindakan ummatnya karena kekerasan adalah bagian dari tindakan amoral yang memiliki unsur pemaksaan bagi pihak lain untuk mengikuti aturan yang ditetapkan, artinya ada pemaksaan kehendak yang melanggar kebebasan dalam kehidupan sosial-politik.

Dalam rentangan sejarah agama selalu memiliki peran ganda, yaitu sebagai inisiator perdamaian demi terciptanya tatanan sosial yang ideal, anti keterbelakangan dan selalu membawa pesan kedamaian. Peran yang tidak bisa diabaikan bahwa agama juga penyumbang kekerasan yang mengerikan bagi peradaban manusia. Kekerasan dan agama bila dipahami adalah dua hal yang saling bertentangan, agama selalu mengajarkan kasih sayang dan menyebarkan perdamaian sementara kekerasan adalah bahasa dan tindakan yang bertentangan dengan misi agama.

Kekerasan yang sering dikaitkan dengan agama bukanlah sebuah penyimpangan, setidaknya ini menurut Mark Juergensmeyer, dia menuturkan bahwa apa yang terjadi dari setiap kekerasan agama adalah sebuah cosmic war. Perang kosmik yang dipahami dari sumber ajaran agama adalah bahwa setiap pemeluk agama senantiasa menghadapi ancaman dari segala bentuk kejahatan (evil), sehingga manusia beragama harus memeranginya untuk menegakkan kebaikan dan kebenaran di muka bumi. Dari pandangan ini kekerasan memiliki struktur yang mendasar dari hampir semua sistem kepercayaan yang terdapat dalam agama-agama besar di dunia (Juergensmeyer, 1994, pp. 155-159).

Ajaran agama tidak dapat dipisahkan dari pemeluknya, secara konkret sebuah agama akan bernilai ketika ada penghayatan yang tulus dari pemeluknya untuk menjalankan semua yang diperintahkan oleh agama. Dalam realitas sosial, pemisahan antara agama dan pemeluknya tidak mungkin terjadi (Trigg, 1998, pp. 29-32). Artinya hubunganya dengan kekerasan adalah bahwa agama menolak kekerasan secara normatif dapat dipahami, akan tetapi agama tidak hanya meliputi dogma dan norma melainkan juga lembaga yang juga rentan terhadap proses transformasi sosial. Oleh karena itu agama sering melegalkan tindakan yang secara tidak langsung mereduksi makna keberagamaannya. Agama dalam hal ini begitu sulit menjadi dasar atau pijakan yang diarahkan untuk mengatasi persoalan sosial yang semakin kompleks (Sunardi, 1996, p. 174). 
Kondisi yang lebih parah jika agama dipolitisir oleh sebagian kalangan untuk menggalang masa yang banyak sebagai upaya mencapai tujuan tertentu yang tidak sejalan dengan ajaran agama demi menggeser kelompok lain yang dianggap tidak sepaham dan tidak sejalan. Selain itu agama juga menjadi alat yang ampuh untuk menebarkan kebencian dengan kemasan kesalehan, fakta menunjukkan bahwa dendam sejarah dari akibat kekerasan yang berbau agama senantiasa menjadi bom waktu yang siap meledek kapan saja dan di mana saja dengan atas nama Tuhan.

Relasi agama tidak hanya pada perdamaian semata akan tetapi juga terhadap kekerasan, agama sering dijadikan landasan ideologis bagi pembenaran tindakan kekerasan yang dilakukan oleh umat beragama. Menurut Hariyatmoko setidaknya ada tiga alasan mengapa agama dijadikan legitimasi kekerasan. Pertama, adalah karena fungsi agama sebagai ideologi. Dalam fungsi ini agama kemudian menjadi perekat suatu masyarakat karena memberi kerangka penafsiran dalam pemaknaan relasi antar manusia, yakni sejauh mana tatanan sosial di anggap sebagai representasi religius, yang dikehendaki Tuhan. Lebih jauh fungsi perekat ini, di sisi lain juga bisa menghasilkan banyak kontradiksi terutama menyangkut masalah ketidakadilan dan kesenjangan yang selalu menjadi topik yang panas dan acapkali melahirkan tindak kekerasan.

Kedua, adalah fungsi agama yang juga sebagai faktor identitas. Agama secara spesifik dapat di identikkan kepemilikannya pada manusia atau kelompok manusia tertentu. Kepemilikan ini memberi stabilitas, status, pandangan hidup, cara berpikir, etos dan sebagainya. Hal ini lebih mengkristal lagi bila dikaitkan dengan identitas lainnya seperti seksual (jenis kelamin), etnis (kesukuan), bangsa dan sebagainya. Pertentangan etnis, kelompok, bangsa dan sebagainya sangat mungkin melahirkan kekerasan dan di sini agama sangat mungkin untuk turut diikutsertakan juga.

Ketiga, fungsi agama sebagai legitimasi etis hubungan antar manusia. Berbeda dengan agama sebagai kerangka penafsiran, mekanisme ini bukan sakralisasi hubungan antar manusia, tetapi suatu hubungan antar manusia yang mendapat dukungan dan legitimasi dari agama. Padahal orang tahu, di dunia apalagi dunia ketiga, ekonomi pasar sangat akomodatif terhadap rezim antidemokrasi, yakni represif terhadap gerakan kesetaraan dan biang dari kekerasan struktural. Dengan demikian potensi agama untuk diikutsertakan dalam tindak kekerasan sebagai "landasan dan legitimasi" menjadi sangat memungkinkan.

Budaya kekerasan yang laten terinspirasi oleh spririt agama dikalangan masyarakat oleh Johan Galtung diklasifikasikan dalam tiga-tipe kekerasan yang saling bertalian; kekerasan langsung, kekerasan struktural, kekerasan budaya. Kekerasan langsung merupakan suatu peristiwa, kekerasan struktural merupakan suatu proses yang mengalami pasang surut dan kekerasan budaya yang lebih bersifat invariant, permanence, dan cenderung berjalan stabil sesuai transpormasi budaya dasar yang juga lamban (Galtung, 2002, pp. 187-188).

Ketiga teori kekerasan tersebut dapat dicitrakan sebagai segitiga kekerasan yang saling mendukung satu sama lain. Cara kerja ketiga bentuk 
kekerasan tersebut berdasarkan arus kausal yang berantai dari satu titik ke titik lainnya di mana siklus yang menghubungkan ketiga jenis kekerasan tersebut bisa bermula dari titik yang mana saja (Galtung, 2002, p. 189). Teori Galtung ini senada dengan apa yang dikemukakan oleh Dom Helder Camara yang menjelaskan tiga bentuk kekerasan. Yaitu kekerasan personal, institusional dan struktural; kekerasan yang bermula dari ketidakadilan, lalu muncul kekerasan pemberontakan sipil, dan kemudian lahir kekerasan sebagai represi negara. Ketiganya berkaitan satu sama lainnya, kemunculan kekerasan yang satu disusul dan menyebabkan kemunculan kekerasan yang lainnya (Camara, 2000). Agama dapat terperangkap dalam spiral kekerasan ketika agama berada dalam kondisi yang tidak berjarak dengan kekuasan. Artinya agama dapat dijadikan justifikasi pembenaran akan tindakan kekerasan yang dilakukan oleh penguasa.

St. Sunardi menggolongkan kekerasan agama ke dalam tiga tipe. Pertama, kekerasan intern agama. Kekerasan ini biasanya terjadi dalam agama tertentu. Ketidaksepemahaman atau ketidaksetujuan atas sebuah persoalan dalam persoalan interpretasi ajaran tertentu sering menimbulkan reaksi yang berlebihan mana kala terjadi kebuntuan komunikasi antara satu kelompok atau aliran dengan yang lainnya. Kedua, kekerasan akan muncul ketika agama berada pada kondisi masyarakat yang zalim dan penuh dosa di mana agama merasa memiliki tanggung Jawab moral untuk melawannya. Ketiga kekerasan muncul ketika agama merasa terancam oleh kehadiran agama-agama lain. Kekerasan ini dalam lintasan sejarah merupakan kekerasan yang sangat krusial (Sunardi, 1996, pp. 172-173).

Sementara Hasan Hanafi menegaskan bahwa ada perbedaan antara kekerasan yang menindas (oppressive violence) dan kekerasan revolusioner (revolutionary violence). Oppressive violence adalah kekerasan politik yang dilakukan oleh sebuah rezim yang sedang berkuasa untuk melakukan ketidakadilan sosial dan mempertahankan status-quo. Sedangkan revolutionary violence adalah bentuk pertahanan diri yang dilakukan oleh rakyat dalam kapasitasnya menentang ketidakadilan sosial dan tekanan militer. Oppressive violence dipahami sebagai kekerasan yang menekan sementara revolutionary violence dipahami sebagai kekerasan yang membebaskan. Kekerasan yang pertama adalah murni penyerangan sedangkan kekerasan yang kedua adalah upaya pertahanan diri (Hanafi, 2001, pp. 53-54).

Konflik dan kekerasan cenderung terkonsentrasi di negara-negara berkembang (dunia ketiga) yang secara tipikal dicirikan dengan jumlah populasi penduduk yang pesat tapi tingkat pemenuhan kebutuhan yang terbatas, keterbelakangan pendidikan, dan kemiskinan. Bertolak dari pandangan di atas kekerasan merupakan fenomena dan persoalan yang complicated, sehingga Pantaleon Iroegbu mengemukakan tiga hal dilema yang telah menenggelamkan umat manusia ke dalam jurang konflik dan kekerasan yang disebut sebagai "tiga segitiga kelam" atau "three vicious triangles", yaitu Agama-Moral-Manusia, Politik-Sosial-Ekonomi, dan Kebodohan-KemiskinanPenyakit (Iroegbu, 1997, p. 352). 
Visi keberagamaan yang terpecah berimplikasi pada sikap dan moral keagamaan yang dangkal, pada gilirannya memunculkan pendangkalan integritas kemanusiaan, baik internal maupun eksternal. Rendahnya integritas kemanusiaan yang ditunjukan dengan aksi-aksi kekerasan merupakan cermin rendahnya keimanan manusia baik sebagai individu maupun masyarakat. Secara politik kondisi semacam ini menimbulkan chaos berdampak pada stabilitas ekonomi dan politik yang mengarah pada krisis multidimensi yang berkepanjangan (Iroegbu, 1997, p. 353).

Fenomena kekerasan agama tidak dapat dilihat secara terpisah sebagai kekerasan agama an sich, melainkan harus diamati sebagai hasil dari keterkaitan berbagai faktor. Mulai dari kemiskinan dan kepincangan sosial dengan sistem kekerasan, polusi dan kelangkaan sumber-sumber pokok dengan sistem ekonomi yang ekspansonis, antara dominasi dan eksploitasi, hingga ke sistem politik represif yang sering dijumpai di banyak negara dunia ketiga (negara berkembang).

Dalam perspektif yang lebih luas, fenomena kekerasan agama tidak dapat dilepaskan dari sumber global konflik dan kekerasan kontemporer. Kekerasan tidak hanya hasil dari faktor psikologis individu, gejolak biologis, atau faktor sosial-kultural, tetapi juga disebabkan oleh suatu jaringan kausal antara struktur, proses dan prilaku level-personal dan level-global. Dalam kerangka ini kecenderungan individu untuk melakukan kekerasan tidak akan terjadi kecuali dalam konteks kultur penyelesaian dengan kekerasan (Kutz \& Turpin, 2002, pp. 200-203).

Proses manajemen konflik di berbagai level dan pengalaman dalam menagangi konflik berdasarkan berbagai pendekatan memiliki plus-minus tersendiri, deeskalasi konflik selalu melihat bagaimana konteks sosial yang menyertainya, secara khusus, politik, ekonomi, dan budaya. Dalam kajian studi perdamaian menurut temuan Mohamad Abu Nimer riset perdamaian masih kalah dominan dengan studi konflik dan kekerasan, oleh karena itu apa yang di istilahkan oleh Nimer dengan bina-damai dan nir-kekerasan (peacebuilding dan nonviolence) menjadi isu yang sangat penting untuk terus dikaji dengan multi perspektif (Nimer, 2010).

Nimer juga menjelaskan dari temuanya bahwa di berbagai daerah yang terjadi konflik, ternyata banyak ditemukan fakta bahwa konflik dapat diselesaikan dengan kearifan lokal yang ada di daerah konflik tersebut, Nimer mengeksplorasi lebih lanjut bahwa kekuatan kearifan lokal mampu menjadi satu alternatif dalam deeskalasi konflik - bahkan untuk merawat kehidupan bersama agar tidak terjadi konflik (bina-damai) - yang sangat efektif (Nimer, 2010).

Mengekspolarasi kekayaan budaya sebagai salah satu alternatif bagaimana mengelola perdamaian atau lebih tepatnya bagaimana melakukan proses bina-damai dan nir-kekerasan di Indonesia sudah harus dilakukan, karena bangsa ini kaya akan tradisi, di mana tradisi sudah menjadi bagian yang tidak terpisahkan dari pola hidup, pola pikir dan membentuk struktur kebudayaan di masyarakat, sehingga kearifan lokal sebagai kekayaan yang 
dapat memberikan solusi agar tidak terjadi konflik yang destruktif sangat urgen untuk dilakukan.

\section{HASIL DAN PEMBAHASAN}

Secara spesifik telaah atas kebudayaan Jawa yang melingkupi berbagai dimensi filosofis, kajian tentang bagaimana orang Jawa menjalani hidup tentu sudah banyak dilakukan oleh para ahli sosiologis dan antropologis, ini mengindikasikan bahwa prilaku manusia Jawa secara umum selalu multidemensi. Kultur Jawa atau tradisi Jawa terkait dengan relasi personal, orang ke orang, antar kelompok dan komunitas tidak serta merta dibangun atas dasar alamiah begitu saja, ada landasan berpikir dan bertindak yang menjadi pondasi sumber nilai dalam setiap gerak kehidupannya, tentu ini bukan hanya berlaku bagi etnis Jawa begitu juga dengan etnis lainnya.

Persoalan relasi antar individu, kelompok atau komunitas dalam sistem kultur Jawa menjadi pondasi atas bentuk dan konstruksi hubungan tersebut, kerukunan menjadi pilar penyangga kehidupan harmonis baik sesama manusia maupun dengan alam. Konsepsi kerukunan dalam sistem kebudayaan Jawa erat kaitanya dengan integrasi masyarakat secara spesifik msyarakat desa yang masih memegang teguh norma dan etika budaya.

Integrasi sebuah msyarakat dengan adanya kerukunan tidak berarti menghilangkan konflik, apalagi dalam masyarakat majemuk baik agama maupun etnis. Konflik disini dapat berbentuk laten dan manifest. Dahrendorf menguraikan tentang masalah yang cukup krusial dan senantiasa muncul dalam kehidupan bermasyarakat yakni adanya konflik kepentingan. Masyarakat monolitik dan pluralistisk sering terjebak dalam nuansa konflik kepentingan yang dimiliki dari masing-masing entitas yang berbeda dan bertentangan (incompability) kemudian sulit ditemukan solusinya (Ritzer, 1982). Di satu sisi satu kelompok ingin kepentingannya menjadi prioritas, di sisi yang lain, kelompok yang berbeda juga memiliki keinginan yang sama. Pergeseran dua kepentingan yang dimiliki dua kelompok berbeda, tidak jarang juga memancing timbulnya konflik.

Dalam mewadahi kepentingan yang berbeda masyarakat desa yang pada umumnya masyarakatnya petani, yakni ruang-ruang sosial untuk bertemu bergantung pada pola kinship atau Gemeinschaft pattern (Parsons, 1997, p. 153; Thomshon, 1996, pp. 23-26), biasanya konflik yang terjadi terkait dengan bentuk kompetisi untuk memenuhi kebutuhan material dan kepentingan ekonomi pribadi (From, 2001, p. 229). Biasanya, pola penyelesaian konflik atau masalah yang muncul melalui pendekatan kekeluargaan. Pasa kasus yang demikian, kewibawaan seseorang yang sangat dihormati di dalam kelompok menentukan jalannya proses penyelesaian masalah yang timbul. Cara ini terbukti efektif karena logika berpikir yang berpijak pada aspek kekeluargaan (Koentjaraningrat, 1981, p. 158).

Menghadapi berbagai potensi konflik yang oleh Menurut Hobbes dijelaskan bahwa konflik adalah peristiwa natural atau alamiah dan tidak 
mungkin dapat dihindari dalam kehidupan sosial manusia. Catatan sejarah membuktikan bahwa terjadi konflik sosial dalam setiap masanya (Windhu, 1991, p. 63). Argumentasi lain diuraikan oleh Roger M. Keesing, ia menjelaskan manusia mempunyai watak alamiah untuk mendorong terjadinya konflik. Menurutnya, ciri-ciri karakter manusia yang berperilaku agresif adalah watak kehendak merampas wilayah, kemudian sifat ingin senantiasi bersaing dengan individu atau kelompok lainnya. Dia mencontohkan bahwa laki-laki memiliki kecenderungan akan sifat dominan ke pihak wanita, begitu juga sebaliknya pihak wanita memiliki kecenderungan menguasai atas laki-laki (Keesing, 1999, p. 20).

Menyadari bahwa konflik adalah bagian dari elemen kehidupan, kultur Jawa membangun pemahaman tentang arti pentingnya sebuah kerukunan dalam sebuah masyarakat yang akan membentuk satu integrasi sosial. Faktor pendukung yang menjadikan masyarakat Jawa pada umumnya memiliki integrasi sosial yang baik adalah adanya konsep "guyup rukun" dalam kehidupan rumah tangga dan bertetangga yang bersumber dari kebudayaan Jawa (Neils Mulder, 1984, p. 64). Pada sisi lain, bentuk kehidupan keberagamaan (religiositas) yang tertutup atau fanatik merupakan sumber konflik sosial dalam kehidupan masyarakat (Kleden, 1984).

Hal lain yang menjelaskan tentang masyarakat Jawa dalam beragama adalah uraian dari Frans Magnis Suseno yang mengatakan dengan jelas bahwa orang Jawa membenci dogmatisme, eksklusivisme, fanatisme, kepicikan agama dan kesombongan. Hal ini tidak berarti agama hanya urusan pribadi semata, akan tetapi orang juga harus ikut merasakan ke mana dan di mana, Tuhan berseru kepadanya. Dalam tradisi alam berpikir Jawa, kebebasan orang untuk mencari makan dirinya sendiri di dalam jiwanya untuk menemukan Tuhan sangat dihormati (Magnis-Suseno, 2007, p. 61).

Ada tiga hal yang menjadi sumber konflik dalam masyarakat Indonesia, setidaknya analisis dari Koentjaraningrat mengemukakan hal tersebut, antara lain ketika antar warga masyarakat: saling bersaing dalam lapangan mata pencaharian, saling memaksakan unsur-unsur dari kebudayaannya dan atau agamanya dan terakhir saling mendominasi secara politik (Koentjaraningrat, 1979, p. 377).

Dalam masyarakat multireligius seperti masyarakat Turgo Lereng Merapi misalnya, sebagai masyarakat Jawa yang pluralistik secara agama, meyakini bahwa hidup berdampingan dengan orang yang berbeda agama bukanlah masalah, masyarakat dapat menyatu dengan alam apalagi dengan sesama manusia (Sahfutra, 2012, p. 275). Tentunya ketika terjadi konflik dan benturan khususnya antar agama, pemeluk agama dengan pengetahuan kebudayaan yang dimilikinya mengaktifkan bagian-bagian tertentu dari ajaran agamanya yang dianggap mampu menjelaskan keberadaannya dalam kehidupan dan dalam menghadapi lingkungannya yang diambil sebagai dasar pembenaran (Saifuddin, 1986, p. 9). Menurut Durkheim, hal tersebut terjadi karena agama salah satu fungsinya adalah sebagai sumber moralitas bagi komunitas penganutnya, dan justru karena fungsinya itulah suatu agama dapat "survive" dalam kehidupan bermasyarkat (Turner, Beeghley, \& Power, 1998, p. 243). Sementara itu, bagi masyarakat kota atau kelompok modernis seperti 
Muhammadiyah juga menunjukkan sikap keberagamaan yang toleran terhadap keberadaan kelompok dan agama lain. Sekalipun terjadi misalnya pertentangan terkait misi agama (Riyadi, 2016, p. 25).

\section{Bina-Damai dalam Alam Pikiran Jawa}

Paradigma kerukunan yang dimiliki manusia Jawa untuk menjadi sumber relasi antar individu dan kelompok setidaknya dibangun atas dua kaidah dasar dalam masyarakat Jawa, seperti anggapan dan penjelasan Hildred Geertz yang menyatakan bahwa setidaknya terdapat dua kaidah yang sangat menentukan bentuk pergaulan di masyarakat Jawa. Pertama, kaidah yang menjelaskan dalam kondisi apapun sebaiknya senantiasa bersikap sedemikian rupa agar terhindar dari konflik dalam bentuk apapun. Kedua, menganjurkan agar manusia dalam tindak-tanduknya khususnya berbicara selalu menunjukkan sikap hormat kepada orang lain, sesuai dengan posisinya (H. Geertz, 1961, p. 146).

Franz Magnis-Suseno mencoba menerjemahkan dua kaidah dasar yang dipahami oleh H. Geertz tersebut, yaitu kaidah pertama, Magnis menyebutnya sebagai "prinsip kerukunan" dan kaidah kedua dia sebut dengan "prinsip hormat". Lebih tegas Magnis-Suseno menjelaskan bahwa dua kaidah dasar itu adalah basis standar orang Jawa dalam semua aktivitasnya dalam berinteraksi dengan orang lain. Selain dua kaidah itu dengan penuh kesadaran telah dan selalu ditanamkan oleh para orang tua kepada anak-anaknya agar hidup dan berinteraksi dengan dua kaidah atau dua prinsip tersebut (Magnis-Suseno, 1991).

Prinsip kerukunan dalam alam pikiran Jawa setidaknya dapat dipahami dari pengertian yang dijelaskan oleh Mulder yang dielaborasi oleh Magnis-Suseno yaitu, prinsip kerukunan memiliki tujuan yakni menjaga kondisi masyarakat agar senantiasa dalam keadaan harmonis. Kondisi yang demikian dapat disebut dengan rukun. Rukun maknanya adalah "berada dalam kondisi atau keadaan selaras", "tenang dan tentram", "tanpa perselisihan dan pertentangan", "bersatu dalam maksud untuk saling membantu" (Niels Mulder, 1978, p. 39).

Mulder lebih jauh menjelaskan bahwa "rukun" terdapat di mana semua pihak berada dalam keadaan damai satu sama lain, suka bekerja sama, saling menerima, dalam suasana tenang dan sepakat. Rukun merupakan kondisi yang selalu diharapkan dapat bertahan dalam semua relasi sosial, di keluarga, dengan tetangga, dengan anggota masyarakat di desa, bahkan dalam setiap kelompok dan komunitas yang ada di masyarakat. Hal yang demikian merupakan semangat dari kerukunan (Niels Mulder, 1978, p. 39).

Secara etimologi kata "rukun" menurut Jay adalah bermuara pada tindakan (Jay, 1969, p. 66). Bersikap rukun sama halnya meniadakan tanda ketegangan struktur relasi masyarakat atau diantara jalinan relasi individu, kelompok masyarakat, yangpada akhirnya berdampak pada hubungan sosial senantiasa baik dan selaras (H. Geertz, 1961, p. 146). Rukun berarti usaha yang terus dilakukan oleh semua pihak, agar bersikap tenang, dengan segenap usaha agar hal-hal yang menimbulkan perselisihan dan keresahan dapat hilang. Tuntutan kerukunan merupakan kaidah penata masyarakat yang menyeluruh. 
Segala apa yang dapat mengganggu keadaan rukun dan suasana keselarasan dalam masyarakat harus dicegah (Magnis-Suseno, 1991, p. 39).

Sejelan dengan prinsip kerukunan dalam alam pikiran Jawa, hal lain yang menambah kuat prinsip kerukunan tersebut adalah falsafah hidup orang Jawa yang memiliki adigium dalam pedoman diri, istilah " rame ing gawe" yang diartikan sebagai pemenuhan kewajiban di dunia demi pemeliharaan masyarakat. Setiap manusia yang sudah sepi ing pamrih (lepas dari egosime individual) maka ia tidak lagi mengejar kepentingan diri sendiri tapi kepentingan bersama, keselarasan secara keseluruhan. Maka ia telah berada di tempat yang tepat di dunia ini dengan sendirinya.

Menurut Magnis-Suseno, ada dua segi yang harus diperhatikan dalam tuntutan kerukunan. Pertama, dalam pandangan Jawa masalahnya bukan penciptaan keadaan keselarasan sosial, melainkan lebih untuk tidak mengganggu keselarasan yang diandaikan sudah ada. Dalam perspektif Jawa lanjut MagnisSuseno, ketenangan dan keselarasan sosial merupakan keadaan normal yang akan terdapat dengan sendirinya selama tidak diganggu, seperti juga permukaan laut dengan sendirinya halus kalau tidak diganggu oleh angin atau oleh badan-badan yang menentang arus. Kedua, prinsip kerukunan pertama-tama tidak menyangkut suatu sikap batin atau keadaan jiwa, melainkan penjagaan keselarasan dalam pergaulan. Yang diatur adalah permukaan hubunganhubungan sosial yang kentara. Yang perlu dicegah ialah konflik-konflik terbuka. Supaya manusia dapat hidup sesuai dengan tuntutan kerukunan dengan mudah dan enak, titik tekannya adalah agar kententraman dalam masyarakat jangan sampai diganggu, meskipun ada perselisihan dan pertentangan namun jangan sampai hal itu kelihatan (Magnis-Suseno, 1991, p. 40).

\section{Prinsip Keseimbangan dalam Masyarakat Jawa}

Masyarakat Jawa dalam proses mempertahankan prinsip keseimbangan hidup senantiasa berupaya untuk membentuk satu sistem sosial yang mendukung integrasi baik dengan manusia maupun dengan alam sekitar. Geertz dengan tesisnya menguraikan tentang unsur-unsur integrasi sosial yang mengilhami penyatuan masyarakat Jawa, yang menurutnya sistem tersebut cenderung menjadi benteng masyarakat dari unsur pemecah belah, yakni: (1) munculnya watak kesadaran akan kesatuan kebudayaan, yakni rasa memiliki satu kesamaan budaya, di dalamnya termasuk rasa nasionalisme terhadap suku maupun bangsa, karakter ini memiliki kecenderungan menghindar dalam mempermasalahkan perbedaanya; (2) hadirnya beragam individu dan kelompok dengan tipe campuran dan kelompok dengan tipe marjinal, kedua tipe tersebut berperan dalam struktur sosial sebagai perantara antara alam berpikir Jawa dengan non-Jawa. Hal demikian dikarenakan oleh adanya kenyataan jika pola keagamaan tidak selalu diungkapkan secara terus terang dan langsung, melainkan melalui proses yang lumayan rumit, sehingga komitmen dalam hal keagamaan dan komitmen dalam hal lainnya senantiasa seimbang; (3) hadirnya konsep tentang toleransi dan integrasi sosial yang majemuk, yakni toleransi umum yang disandarkan kepada apa yang disebut dengan "relativisme kontekstual" yaitu anggapan tentang nilai-nilai tertentu sesuai tidak berbeda 
dengan konteksnya, sehingga mampu memperkecil tujuan-tujuan khusus yang bertentangan dengan integrasi sosial; dan (4) dibentuknya hari-hari besar sebagai ekspresi budaya dalam bentuk upacara adat, yang menjelaskan tentang bagaimana intergrasi sosial itu dibutuhkan dalam kehidupan bersama, sehingga terhindar dari konflik yang tidak berguna (C. Geertz, 1983).

Atas dasar tesis ini, Geertz menegaskan bahwa diantara faktor-faktor di atas, faktor yang terpenting sebagai integrasi sosial dalam agama Jawa adalah; "kesadaran akan kesatuan kebudayaan". Adapun dua bentuk utama dari kesadaran ini adalah: Pertama, "tradisionalisme dan warisan budaya bersama", yaitu kesadaran yang menyatakan bahwa masa sekarang merosot dibandingkan dengan masa lalu, khususnya kritik terhadap praktek-praktek sekarang yang dilihat menurut ukuran tradisional, terutama sebagian praktek yang dipakai oleh kalangan tua. Kedua, "nasionalisme dan proyeksi kebudayaan bersama yang baru", yaitu kesadaran yang semakin tumbuh ketika sebagian kalangan mencoba mengangkat harkat bangsa, solidaritas, dan keinginan menjalankan cara hidup yang lebih modern untuk menghambat ketidakteraturan sosial, terutama di kalangan muda.

Masyarakat pedesaan Jawa senantiasa melakukan ritual sebagai bentuk penghormatan terhadap para leluhur yang sudah meninggal maupun untuk makhluk halus penghuni kampung, hal ini sebagai bentuk menjaga keseimbangan hubungan antara dunia realitas dan dunia lain (kosmos) yang menjadi panduan orang Jawa dalam menjalani hidup.

\section{1) Harmoni dengan Manusia}

Menjaga keseimbangan hidup agar kehidupan dapat berjalan secara harmonis dan berkelanjutan orang Jawa senantiasa menjaga hubungan baik sesama anggota masyarakat atau orang lain sekaligus juga menjaga hubungan baik dengan alam. Alam bagi masyarakat Jawa seperti yang pernah dijelaskan di atas dianggap sebagai makhluk yang memiliki kekuatan di luar kekuatan manusia. Dalam istilah Geertz disebut dengan alam Numinus (C. Geertz, 1983, p. 118). Hubungan sesama orang Jawa sudah dibangun sejak kecil bagaimana pola dan bentuk komunikasi dan tingkah laku sudah diajarkan, semua itu untuk menjaga keharmonisan antara orang Jawa, masyarakat bagi orang Jawa pertama terwujud dalam keluarganya sendiri, dimana ia termasuk bagian dari anak, adik, atau kakak dan orang tua, kemudian para tetangga, keluarga yang lebih jauh dan akhirnya seluruh desa. Dalam lingkungan ini ditemukan identitas dan keamanan fisiknya (Magnis-Suseno, 1991, p. 85).

Keharmonisan orang Jawa dapat dilihat secara umum bagaimana upaya membangun relasi dengan cara menghormati orang lain dilihat dari posisi dan bentuk sapaannya. Oleh karena itu orang Jawa berusaha untuk memperlakukan orang lain dan anggota keluarga, orang lain yang bukan dari anggota keluarga senantiasa disapa dengan sapaan untuk anggota keluarga, seperti: pak, bu, mbah, pakdhe, paklik, budhe, bulik, mbakyu, mas, dhik, dan seterusnya (Magnis-Suseno, 1991, p. 49). 
Bentuk lain dari relasi hubungan manusia dengan manusia lain terlihat ketika pada momen dan kesempatan tertentu orang Jawa senantiasa mengirim makanan yang sudah masak bagi anggota keluarga besar. Siapa yang mendapatkan keuntungan istimewa diharapkan membagi bagi kepada anggota keluarga terdekat, dan siapa yang memiliki kekayaan yang berlebih harus dibagikan dan membantu orang lain, seperti misalnya siapa yang memiliki sawah luas dan banyak harus mengikutsertakan tetangganya dan orang lain dalam masa panenan. Seperti ungkapan pribahasa: ada sedikit diberi sedikit, ada banyak dibagi banyak.

Filosofi gotong-royong dalam masyarakat Jawa juga bagian dari cerminan bagaimana relasi hubungan untuk membangun keharmonisan bagi sesama manusia. Praktek gotong-royong adalah bagian dari upaya membangun kerukunan, setidaknya terdapat dua motif diadakannya gotongroyong yaitu: saling membantu dan melakukan pekerjaan bersama demi kepentingan seluruh desa. Pertama adalah untuk membantu tetangga dalam membangun rumah, persiapan pesta, dan pada kesempatan lain dan aktivitas tertentu (Magnis-Suseno, 1991, p. 50).

Kedua adalah demi kepentingan desa, misalnya pelebaran jalan, perbaikan irigasi atau bendungan, pembangunan sekolah, perbaikan jembatan, pembersihan kuburan, ronda malam dan bahkan ada pembangunan rumah ibadah. Menurut Koentjaraningrat, ada tiga nilai yang disadari orang desa dalam melakukan gotong royong: Pertama, orang itu harus sadar bahwa dalam hidupnya pada hakikatnya dia selalu tergantung pada sesamanya, maka dari itulah dia harus selalu berusaha untuk memelihara hubungan baik dengan sesamanya. Kedua, orang itu harus selalu bersedia membantu sesamanya. Ketiga, orang itu harus bersifat conform, artinya orang harus selalu ingat bahwa dia sebaiknya jangan berusaha untuk menonjol, melebihi yang lain dalam masyarakatnya (Koentjaraningrat, 1969, p. 35). Hal ini sebagai upaya untuk tetap menjaga keseimbangan dan keharmonisan sesama manusia.

Usaha untuk membangun harmoni dan kerukunan sesama manusia juga mendasari kebiasaan musyawarah, yaitu proses pengambilan keputusan dengan saling berkonsultasi, Mulder memberikan komentar agak panjang terkait bagaimana musyawarah dilakukan orang Jawa, "secara ideal musyawarah adalah prosedur di mana semua suara dan pendapat didengarkan. Semua suara dan pendapat dianggap sama benar dan membantu untuk memecahkan masalah. Musyawarah berusaha untuk mencapai kebulatan kehendak atau kebulatan pikiran, tidak ada pemungutan suara dalam musyawarah. Musyawarah merupakan proses pertimbangan, pemberian dan penerimaan, dan kompromis, di mana semua pendapat harus dihormati" (Niels Mulder, 1978, p. 40).

Menurut Jay pertemuan desa (rembug desa) di beberapa daerah terdapat kebiasaan bahwa orang-orang desa mengungkapkan persetujuan mereka terhadap keputusan yang menyangkut seluruh kelompok dengan bersama-sama menjawab inggih (Jay, 1969, p. 399). Magniz-Suseno mengomentari hal tesebut dengan menyatakan bahwa pendapat-pendapat yang berlawanan diungkapkan 
secara tidak langsung dan sopan, biasanya melalui sindiran atau dengan tidak menanggapi pertanyaan yang diajukan (Magnis-Suseno, 1991, p. 52).

2) Harmoni dengan Alam

Di luar hubungan harmoni manusia Jawa dengan sesamanya orang Jawa juga membangun harmoni dengan alam. Posisi alam dalam relasi manusia dengan manusia lain menurut orang Jawa juga harus disetarakan, bahwa alam adalah makhluk hidup yang harus dibangun suatu relasi dan sikap yang harmonis sehingga alam dapat bersahabat dengan manusia. Alam memiliki posisi tersendiri dalam alam pikiran Jawa, keteraturan alam menentukan keteraturan hidup manusia, melalui sesama manusia dan masyarakat orang Jawa belajar mengenal alamnya. Adanya siang dan malam, musim hujan dan musim kering menentukan rencana kehidupannya sehari-hari. Dari lingkungan sosial orang Jawa menyadari bahwa alam bisa mengancam, tetapi juga dapat memberikan manfaat dan ketenangan. Sehingga laku hidup orang Jawa senantiasa memberikan penghormatan dan senantiasa mengaitkan hubungan manusia dengan alam secara jelas (Magnis-Suseno, 1991, p. 85).

Alam dipahami memiliki kekuatan tersendiri sehingga kekuatan tersebut jangan sampai mengancam eksistensi manusia. Jika masyarakat dipahami sebagai tempat yang mampu memberikan rasa aman begitu juga dengan alam dihayati sebagai kekuasaan yang menentukan keselamatan dan kehancuran. Alam yang dipahami oleh orang Jawa bukan berhenti pada alam material akan tetapi juga alam non-material yaitu alam inderawi (alam gaib) yaitu misteri yang berkuasa mengelilinginya.

Alam adalah ungkapan kekuasaan yang akhirnya menentukan kehidupan manusia, dalam alam manusia menyadari betapa manusia bergantung dari kekuasaan adiduniawi yang tidak dapat diperhitungkan, benda-benda materi, peristiwa-peristiwa kehidupan sehari-hari, merupakan suatu kesatuan yang terkoordinasi dan teratur, di mana setiap gejala tidak hanya dipahami dari apa yang tampak tapi melebihi dari apa yang sebenarnya manusia tidak mampu untuk memahaminya (Niels Mulder, 1978, p. 17).

Sasongko menjelaskan keterkaitan integrasi antara manusia Jawa dengan alam, bahwa orang Jawa dididik bukan untuk menaklukkan alam melainkan beradaptasi dengan alam, hal ini dikarenakan dalam alam berpikir Jawa alam memiliki kekuatan gaib yang tidak boleh diganggu dan harus dihormati, jika tidak maka alam bisa marah dan murka ke pada manusia dalam bentuk bencana alam (Triyoga, 2010, p. 10).

Bagi orang Jawa, alam empiris berhubungan erat dengan alam metaempiris (alam gaib), kepekaan terhadap dimensi gaib dunia empiris menemukan ungkapannya dalam berbagai cara, misalnya dalam upacaraupacara rakyat dimana setiap proses kehidupan memiliki kekuatan tersendiri misalnya ketika orang Jawa ingin menanam pagi maka akan ada ritual untuk menghormati Dewi Sri (dewi padi).

Kesatuan masyarakat dan alam adikodrati dilaksanakan orang Jawa dengan prilaku sikap hormat terhadap nenek moyang. Sifat gaib alam 
menyatakan diri melalui kekuatan-kekuatan yang tidak tampak, orang Jawa mempersonifikasikanya dengan berbagai istilah, seperti Dhanyang (cikal-bakal desa) ada yang mengagetkan manusia (memedhi), ada lelembut yang bisa merasuk kedalam diri manusia, keberadaanya sering di pohon-pohon besar pada persimpangan jalan, di dekat sumur dan di tempat lain. Sakit dan kecelakaan bahkan dianggap dan diyakini disebabkan oleh roh-roh tersebut, begitu juga dengan sukses dan kebahagiaan (C. Geertz, 1983, pp. 16-29).

Orang Jawa meyakini bahwa dunia sebagai tempat di mana kesejahteraannya tergantung dari apakah dia berhasil untuk menyesuaikan diri dengan kekuatan-kekuatan gaib dan angker tersebut, sehingga agar kekuatan gaib tersebut tidak menimbulkan bencana orang Jawa biasanya mempersembahkan sesajen yang terdiri dari makan kecil dan bunga, baik di rumah, sawah dan tempat yang diyakini dapat menimbulkan bencana.

Ritus religius terpenting dalam masyarakat Jawa adalah slametan. Slametan diadakan pada semua peristiwa penting dalam hidup seperti kehamilan, kelahiran, sunat, perkawinan, pemakaman, sebelum panen, sebelum melakukan perjalan besar, sesudah naik pangkat. Slametan dilakukan dengan makan bersama, semua tetangga harus diundang, di atas nasi yang berbentuk kerucut (nasi tumpeng) diucapkan doa dan mantra oleh modin, kemudian hadirin menyantap makanan yang tesedia, tidak jarang para hadirin membawa bontot pulang untuk anggota keluarga (Magnis-Suseno, 1991, p. 89).

Slametan dapat dipahami sebagai ritus pemulihan slamet, dikarenakan pada acara tersebut banyak tetangga yang hadir maka slametan mengungkapkan pesan bahwa di antara para tetangga terdapat kerukunan dan keselarasan dan dengan demikian keadaan ketentraman masyarakat dapat diperbaharui dan kekuatan-kekuatan berbahaya dapat diminimalisir. Acara slameten juga memuat doa-doa sehingga roh-roh yang ada di sekitar kehidupan mereka dapat juga menikmati acara tersebut dengan memakan sari makanan yang disediakan sebagai sesajen. Dengan demikian, slametan merupakan ritus yang mengembalikan kerukunan dalam masyarakat dan dengan alam adikodrati, alam gaib, dan dengan demikian diyakini dapat mencegah gangguan-gangguan terhadap keselarasan kosmis (Koentjaraningrat, 1979, pp. 95-97).

Dengan dilaksanakannya slametan maka diyakini makhluk halus atau rohroh tidak akan mengganggu kehidupan orang yang melaksanakan dan menghadiri acara tersebut. Catatan Geertz menjelaskan bahwa bila seseorang melaksanakan slametan maka tidak ada pembedaan antara satu orang dengan orang yang lain dan juga dengan roh-roh halus tidak akan mengganggu (C. Geertz, 1983, p. 17).

\section{PENUTUP}

Masyarakat Jawa sebagaimana diuraikan dalam pembahasan di atas, memberikan gambaran tentang bagaimana kontruksi alam berpikir, tindaktanduk serta bagaimana kehidupan sehari-hari dilalui oleh orang Jawa. 
Sehingga dalam sistem sosial kemasyarakatan orang Jawa banyak melahirkan tradisi budaya yang kental dengan nuansa damai. Proses bina-damai ini tidak hanya antara manusia dengan manusia melainkan lebih jauh dari itu, alam kosmologis Jawa juga meyakini bahwa berdamai dengan manusia tidak cukup melainkan juga harus berdamai dengan alam. Pentingnya keteraturan hubungan antar manusia diyakini juga akan berdampak pada keteraturan kosmos, yakni hubungan baik antara manusia dengan alam yang juga bagian dari makhluk ciptaan Tuhan.

\section{REFERENSI}

Camara, D. H. (2000). Spiral Kekerasan. (K. Apiru, Trans.). Yogyakarta: Pustaka Pelajar.

From, E. (2001). Akar Kekerasan. Yogyakarta: Pustaka Pelajar.

Galtung, J. (2002). Kekerasan Budaya. In T. Santoso (Ed.), Teori-teori Kekerasan. Jakarta: Ghalia Indonesia\& Universitas Kristen Petra.

Geertz, C. (1983). Abangan, Santri, Priyayi dalam Masyarakat Jawa. Jakarta: Pustaka Jaya.

Geertz, H. (1961). The Javanese Family: A Study of Kinship and Socialization. New York: The Free Press.

Hanafi, H. (2001). Agama, Kekerasan dan Islam Kontemporer. (A. Nadjib, Trans.). Yogyakarta: Kanisius.

Iroegbu, P. (1997). Ethnicism and Religion in Conflict. Journal of Dharma, XXII(31).

Jay, R. R. (1969). Javanese Villagers: Social Relations in Rural Modjokuto. Massachusetts: The M.I.T. Press.

Juergensmeyer, M. (1994). The New Cold War? Religious Nationalism Confronts the Seculer State. London: University of California Press.

Keesing, R. M. (1999). Antropologi Budaya. Jakarta: Erlangga.

Kleden, I. (1984). Soedjatmoko, Sebuah Psikologi Pembebasan. In Soedjatmoko (Ed.), Etika Pembebasan. Jakarta: LP3ES.

Koentjaraningrat. (1969). Rintangan-rintangan Mental dalam Pembangunan Ekonomi di Indonesia. Jakarta: Bharata.

Koentjaraningrat. (1979). Aneka Warna Manusia dan Kebudayaan Indonesia. In Manusia dan Kebudayaan di Indonesia. Jakarta: Djambatan.

Koentjaraningrat. (1981). Pengantar Ilmu Antropologi. Jakarta: Rineka Cipta.

Kutz, L. R., \& Turpin, J. (2002). Menguraikan Jaringan Kekerasan. In T. Santoso (Ed.), Teori-teori Kekerasan. Jakarta: Ghalia Indonesia \& Universitas Kristen Petra.

Magnis-Suseno, F. (1991). Etika Jawa: Sebuah Analisa Falsafi Tentang Kebijaksanaan Hidup Jawa. Jakarta: PT Gramedia.

Magnis-Suseno, F. (2007). Bisakah Agama-Agama Terbuka Satu Sama Lain? In

T. B. PGI (Ed.), Meretas Jalan Teologi Agama-Agama di Indonesia: Theologia

Religionum. Jakarta: BPK Gunung Mulia.

Mulder, N. (1978). Mysticism and Everyday Life in Contemporary Java: Cultural

Persistence and Change. Singapore: Singapore University Press.

Mulder, N. (1984). Kebatinan dan Hidup Sehari-hari Orang Jawa. Jakarta: PT 
Gramedia.

Nimer, M. A. (2010). Nirkekerasan dan Bina-Damai dalam Islam Teori dan Praktik.

(R. Panggabean \& I. Ali-Fauzi, Eds.). Jakarta: Pustaka Alvabet dan Yayasan Paramadina.

Parsons, T. (1997). The Sosial System. London and New York: Routledge.

Ritzer, G. (1982). Sosiologi Ilmu Pengetahuan Berwajah Ganda. Jakarta: Rajawali Press.

Riyadi, H. (2016). Koeksistensi Damai dalam Masyarakat Muslim Modernis.

Wawasan: Jurnal Ilmiah Agama Dan Sosial Budaya, 1(1).

Sahfutra, S. A. (2012). Pendekatan Budaya dalam Harmonisasi Relasi Muslim dan Non Muslim. Jurnal Ibda', 10(2).

Saifuddin, A. F. (1986). Konflik dan Integrasi: Perbedaan Faham dalam Islam. Jakarta: Rajawali Press.

Sunardi, S. (1996). Keselamatan Kapitalisme Kekerasan, Kesaksian atas Paradoksparadoks. Yogyakarta: LKiS.

Thomshon, K. (1996). The Language of Sociology. London and New York: Routledge.

Trigg, R. (1998). Rasionality and Religion. Oxford: Rasionality and Religion.

Triyoga, L. S. (2010). Merapi dan Orang Jawa Persepsi dan Kepercayaannya. Jakarta: Gramedia.

Turner, J. H., Beeghley, \& Power, C. (1998). The Emergence of Sosiological Theory. Belmont: Wadsorth Publishing Company.

Windhu, I. M. (1991). Kekuasaan dan Kekerasan Menurut Jhon Galtung. Yogyakarta: Kanisius. 